\title{
The Process of Swatch Analysis for different Textile Fabric
}

\author{
Amit Saha ${ }^{1}$, Anup Saha ${ }^{2}$ \\ ${ }^{1}$ Department of Textile Engineering, City University, Bangladesh \\ ${ }^{2}$ Department of Industrial and Production Engineering, Shahjalal University of Science and Technology, \\ Bangladesh
}

\begin{abstract}
The Textile Sector has been modernized by different ways. Much more production facilities are increasing day by day to meet the present demand of textile goods. Worldwide use of textile has taken a new dimension. On this prospect textile buyers \& producers are making sure of good quality of their products. The fabric swatch analysis is done the important role in this sector. All types of fabric can be analyzed by this way. Here, Swatch analysis has been used for defining woven \& denim fabric. The difference between fabrics comes out by this way. Here shows how to identify fabric easily by different tasks with simple mathematical formula.
\end{abstract}

Keywords:- Swatch Analysis, Fabrication, Construction \& Weave Plan.

\section{INTRODUCTION}

Swatch is a sample strip cut from a piece of Fabric [1]. It is a "sample" which is given by the buyer. During the work of Research \& Development we have to do lot of calculations in every steps [2]. There are some formulas, which we followed to do the calculations. Normally when buyers send CAD [3] then they give the construction \& weave of the fabric. Otherwise in case of their supplied fabric swatch, we have to identify the construction \& weave. The calculation that this study is representing is based on CAD \& also swatch. The fabric can be knit, woven, non-woven \& denim etc.

\section{GENERAL WORK FOR SWATCH ANALYSIS}

"Swatch" is a "sample" which is given by the buyer. Swatch is a sample strip cut from a piece of Fabric. The thing which is done in swatch analysis is given below.

1) Types of Fabric: At first the engineers are assigned to find out type of fabric which is the first step of analyzing a swatch. Whether it is yarn dyed or solid dyed.

Solid dyed is the grey colored fabric. There is no colored yarn available here. Yarn dyed fabric is a type where individual yarns are colored or dyed.

Type: Solid dyed or Yarn dyed

2) Buyer Swatch: Before wash or after wash

- Before wash is the unfinished fabric.

- After wash is the finished fabric.

Basically Garments are after washed fabrics because they are made by finished fabrics.

3) Type of Finish: Regular/Micro Sand/Peach/Carbon Peach

- Regular finish is the fabrics having same touch or appearance both the two sides. Two sides are same of a fabric - Regular.

- Peach finish is the fabrics where two sides are not the same.

- Carbon Peach - A type of chemical treatment here done.

4) Weave: It is the structure for weaving. Which type of structure is used it indicates. It may be Plain, twill, Herring bone, Oxford, Boxy, Dobby, Poplin, Canvas, Otto man, End on end etc.

- Plain is $1 / 1$.

- Twill may be $-2 / 1,3 / 1,2 / 2,4 / 1$.

- Hearing bone $-4 / 1$ and $1 / 4$

- Oxford = Two warp ends available.

- Ottoman $=$ Two weft picks available.

- $\quad$ Boxy $=$ Two ends and two picks. 
5) Yarn Type: It indicates the number of plied Yarn. Single or double.

- Single yarn is only one yarn.

- Double yarns are plied yarns. Here minimum 2 years are found.

6) Yarn Quality: The quality of yarn whether it is Kard/OE/Combed/Compact.

- $\mathrm{OE}=$ Open ends are Coarser Count yarn varies from $6 \mathrm{Ne}$ to $16 \mathrm{Ne}$.

- $\mathrm{Kard}=$ Coarser but higher than $\mathrm{OE}$ varies from $20 \mathrm{Ne}$ to $32 \mathrm{Ne}$.

- $\quad$ Combed $=$ Not Coarser not higher. Varies from $30 \mathrm{Ne}$ to $42 \mathrm{Ne}$.

- Compact $=$ Higher count or finer count yarn. Ranges from $40 \mathrm{Ne}$ to up.

What are the differences between $40 \mathrm{Ne}$ combed and $40 \mathrm{Ne}$ compact yarn?

$>40 \mathrm{Ne}$ compact yarns are more crystal than $40 \mathrm{Ne}$ combed yarn. Compact yarns have less hairiness than combed yarns. Air Suction Mechanism is used in compact yarns for removing hairiness. Compact yarn has less hairiness, more crystalinity [4].

7) Physical EPI: Here ends per inch yarns of fabric are found by Counting Glass.

8) Physical PPI: Here picks per inch yarns of fabric are found by Counting Glass.

9) Physical Weight: It is done by GSM Cutter and then weight is taken by the Balance.

\section{0) Physical warp count:}

Physical Warp Count is completed by taking a number of warp yarns and then takes the length in centimeter scale and then it is multiplied by a constant and then divided by weight of total warp weight. The calculation is given below.

$\{$ Total Ends $\times$ length $(\mathrm{cm}) \times 0.0059\} /$ Weight of Warp Ends $(\mathrm{gm})=$ Count $(\mathrm{Ne})$

\section{1) Physical weft count:}

Physical Weft Count is completed by taking a number of weft yarns and then takes the length in centimeter scale and then it is multiplied by a constant and then divided by weight of total weft weight. The calculation is given below.

$\{$ Total Pick $\times$ length $(\mathrm{cm}) \times 0.0059\} /$ Weight of Weft pick $(\mathrm{gm})=$ Count $(\mathrm{Ne})$

12) Physical Construction: It indicates the construction.

Warp count $\times$ weft count $/$ EPI $\times$ PPI

13) Calculated weight: It is also GSM. It is done by calculation.

$=\{(\mathrm{EPI} / \mathrm{WP} \mathrm{Ne}) \times 0.72\}+\{(\mathrm{PPI} / \mathrm{WP} \mathrm{Ne}) \times 0.73\}$

14) Difference \% between physical \& calculated weight:

$=\{($ Physical weight - Calculated weight $) /$ Physical Weight $\} \times 100$

\section{SWATCH DECISION GIVING}

1) Fabrication: About yarn dyed or solid dyed Printing or dyeing and about thickness, Weave etc.

2) Proposed B/W Construction: A proposed construction is given by experience.

3) Proposed B/W weight: A proposed weight is given by experience

4) Weave: About weave structure.

5) Yarn quality: It indicates the quality of yarn.

6) Finish type: It indicates the finish.

7) Delivery width: The total width of fabric.

Swatch Analysis for different Textile Fabrics is given below. 
Table 1: Swatch Analysis for different Textile Fabric

\begin{tabular}{|c|c|c|c|c|}
\hline \multirow{2}{*}{$\begin{array}{l}\text { PROCESSES } \\
\text { Type of Fabric: }\end{array}$} & \multicolumn{2}{|l|}{ Poplin } & Oxford & Denim \\
\hline & \multicolumn{2}{|c|}{ It is a Yarn dyed fabric. } & $\begin{array}{l}\text { It is a Solid dyed } \\
\text { fabric. }\end{array}$ & $\begin{array}{l}\text { It is a Solid dyed } \\
\text { fabric. }\end{array}$ \\
\hline Buyer Swatch: & \multicolumn{2}{|l|}{$\begin{array}{l}\text { It is a Before wash } \\
\text { Fabric. }\end{array}$} & $\begin{array}{l}\text { It is a Before wash } \\
\text { Fabric. }\end{array}$ & $\begin{array}{l}\text { It is a Before wash } \\
\text { Fabric. }\end{array}$ \\
\hline Type of Finish: & \multicolumn{2}{|c|}{$\begin{array}{l}\text { It is a Regular Finished } \\
\text { fabric. }\end{array}$} & $\begin{array}{l}\text { It is a Regular } \\
\text { Finished fabric. }\end{array}$ & $\begin{array}{l}\text { It is a Regular } \\
\text { Finished fabric. }\end{array}$ \\
\hline Weave: & \multicolumn{2}{|c|}{$\begin{array}{l}\text { It is a Plain poplin } \\
\text { fabric. }(1 / 1) \text {. }\end{array}$} & $\begin{array}{l}\text { It is a Plain poplin } \\
\text { fabric. }(1 / 1) \text {. }\end{array}$ & $\begin{array}{l}\text { It is a Plain Ottoman } \\
\text { fabric with Lycra. }\end{array}$ \\
\hline Yarn Type: & \multicolumn{2}{|c|}{ Single or not plied yarn. } & $\begin{array}{l}\text { Single or not plied } \\
\text { yarn. }\end{array}$ & $\begin{array}{l}\text { Single or not plied } \\
\text { yarn. }\end{array}$ \\
\hline Yarn Quality: & \multicolumn{2}{|c|}{$\begin{array}{l}\text { Warp is Compact and } \\
\text { Weft is also Compact. }\end{array}$} & $\begin{array}{l}\text { Warp is Compact and } \\
\text { Weft is also } \\
\text { Compact. }\end{array}$ & $\begin{array}{l}\text { Warp is Combed } \\
\text { and Weft is also } \\
\text { Combed . Lycra is } \\
\text { 40D. }\end{array}$ \\
\hline Physical EPI: & \multicolumn{2}{|l|}{120} & 110 & 175 \\
\hline Physical PPI: & \multicolumn{2}{|l|}{80} & 70 & 85 \\
\hline Physical Weight: & \multicolumn{2}{|c|}{$\begin{array}{l}(0.96 \mathrm{gm} \times 100) / 33.91= \\
2.83 \mathrm{oz} / \mathrm{yd}^{2}\end{array}$} & $\begin{array}{l}(1.21 \mathrm{gm} \times 100) / 33.91 \\
=3.56 \mathrm{oz} / \mathrm{yd}^{2}\end{array}$ & $\begin{array}{l}(2.05 \mathrm{gm} \times 100) / \\
33.91=6.04 \mathrm{oz} / \mathrm{yd}^{2}\end{array}$ \\
\hline Physical warp count: & \multicolumn{2}{|c|}{$50 \mathrm{Ne}$} & $40 \mathrm{Ne}$ & $32 \mathrm{Ne}$ \\
\hline \multirow{2}{*}{$\begin{array}{l}\text { Physical weft count: } \\
\text { Physical Construction: }\end{array}$} & \multicolumn{2}{|l|}{$50 \mathrm{Ne}$} & $40 \mathrm{Ne}$ & $30 \mathrm{Ne}$ \\
\hline & \multicolumn{2}{|l|}{$50 \times 50 / 120 \times 80$} & $40 \times 40 / 110 \times 70$ & $\begin{array}{l}30 \times 30+40 \mathrm{D} / 175 \\
\times 85\end{array}$ \\
\hline Calculated weight: & \multicolumn{2}{|l|}{$2.896 \mathrm{oz} / \mathrm{yd}^{2}$} & $3.2575 \mathrm{oz} / \mathrm{yd}^{2}$ & $6.954 \mathrm{oz} / \mathrm{yd}^{2}$ \\
\hline $\begin{array}{l}\text { Difference \% between } \\
\text { physical \& calculated } \\
\text { weight }\end{array}$ & \multicolumn{2}{|l|}{$2.332 \%$} & $8.4971 \%$ & $-1.51 \%$ \\
\hline \multicolumn{5}{|c|}{ SWATCH DECISION GIVING } \\
\hline Fabrication: & $\begin{array}{l}\text { 100\% Cotton, Yarn } \\
\text { dyed, Poplin. }\end{array}$ & $\begin{array}{l}100 \\
\text { Can }\end{array}$ & $\begin{array}{l}\% \text { Cotton, Yarn dyed, } \\
\text { vas. }\end{array}$ & $\begin{array}{l}100 \% \text { Cotton and } \\
\text { Lycra, Solid dyed. }\end{array}$ \\
\hline $\begin{array}{l}\text { Proposed B/W } \\
\text { Construction: }\end{array}$ & $50 \times 50 / 128 \times 78$ & $(30-$ & $-30) \times 21^{2} / 108 \times 48$ & $\begin{array}{l}32 \times(30+40 \mathrm{D}) / \\
175 \times 85\end{array}$ \\
\hline $\begin{array}{l}\text { Proposed B/W } \\
\text { weight: }\end{array}$ & $2.85 \pm 0.05 \mathrm{oz} / \mathrm{yd}^{2}$ & 6.10 & $\pm 0.05 \mathrm{oz} / \mathrm{yd}^{2}$ & $6.04 \pm 0.05 \mathrm{oz} / \mathrm{yd}^{2}$ \\
\hline Weave: & Plain poplin. (1/1). & & $\begin{array}{l}\text { ord. } \\
\text { p: Two un plied Yard. } \\
\text { t: Two plied Yard. }\end{array}$ & $\begin{array}{l}\text { Ottoman With } \\
\text { Lycra. }\end{array}$ \\
\hline Yarn quality: & (Compact + Compact) & $(\mathrm{Co}$ & nbed + Kard) & $\begin{array}{l}\text { (Combed }+ \\
\text { Combed) with } \\
\text { Lycra. }\end{array}$ \\
\hline Finish type: & Regular. & Reg & & Regular. \\
\hline Delivery width: & $59 " / 60 "$ & $56 "$ & & $56 " / 57$ \\
\hline
\end{tabular}




\section{BASIC FLOW CHART OF RESEARCH \& DEVELOPMENT}

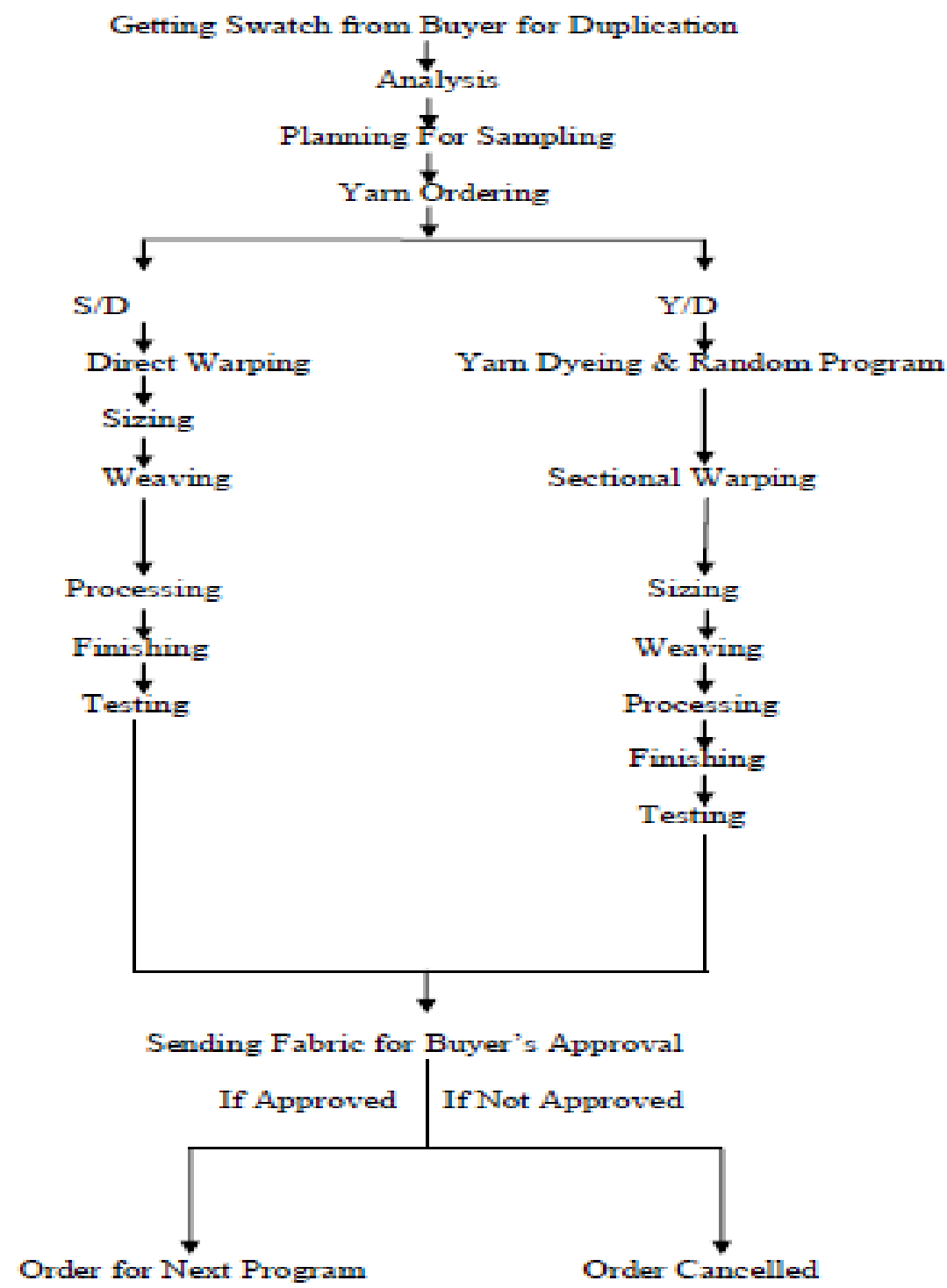

\section{CONCLUSION}

The Textile sector is becoming more competitive day by day. In this prospect the swatch analysis doing vital role. The fabric duplication can easily do by this way. The fabrication of all of fabric can find out. Each fabric has a different construction. Also same fabric has so many constructions. The fabric construction differs from each other. This type of construction can easily get by Swatch analysis. For making any fabric quality of yarn is more important factor. So, it can define yarn quality to ensure good quality of yarn. Swatch analysis gives a brief idea about those particular fabrics which are analyzed. But it has great impact on whole production system of fabric.

\section{REFERENCES}

[1] Rahman. Moshiur. "Fabric Manufacturing Technology Part-2", Books Fair Publications. 2010

[2] Rahman. Moshiur. "Fabric Manufacturing Technology Part-3", Books Fair Publications. 2011

[3] Website: http://en.wikipedia.org/wiki/Computer-aided_design (last modified on 11Jan 2013 at 07:15, Retrieved: 24 Jan 2013)

[4] Rahman. Moshiur. "Fabric Manufacturing Technology Part-4", Books Fair Publications. 2012 